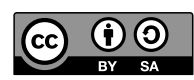

DOI: $10.4312 / \mathrm{mz} \cdot 56.2 .137-152$

UDK 781.7:785:001.891(497.4)

\title{
The Dynamics of Research of Instrumental Traditional Music at the Institute of Ethnomusicology at the Scientific Research Centre of the Slovenian Academy of Sciences and Arts in Past and Present
}

\author{
Teja Turk \\ Research Centre of the Slovenian Academy of Sciences and Arts
}

\begin{abstract}
The article presents the research of instrumental traditional music in the Slovenian space carried out by associates of the ZRC SAZU Institute of Ethnomusicology. It examines the audio resources available for the research of instrumental traditional music practices, as well as the orientations that have had an impact on the interpretation of the collected and analysed material.
\end{abstract}

Keywords: instrumental traditional music, ZRC SAZU Institute of Ethnomusicology, field recordings, $78 \mathrm{rpm}$ gramophone records, research of instrumental traditional music

\section{IZVLEČEK}

$\mathrm{V}$ prispevku so predstavljene raziskave inštrumentalne ljudske glasbe $\mathrm{v}$ slovenskem prostoru, ki so jih doslej opravili sodelavci Glasbenonarodopisnega inštituta ZRC SAZU, in razpoložljivi zvočni viri, ki so na voljo za raziskovanje inštrumentalnih ljudskoglasbenih praks. Prikazane so usmeritve raziskovalcev, ki so vplivale na interpretacije zbranega in že analiziranega gradiva.

Ključne besede: inštrumentalna ljudska glasba, Glasbenonarodopisni inštitut ZRC SAZU, terenski posnetki, gramofonske plošče z $78 \mathrm{o} / \mathrm{min}$, raziskave inštrumentalne ljudske glasbe

The article was written within the framework of young researchers training (No. 50580) and the research programme Folklore and Ethnological Research on Slovenian Folk Culture (No. P6-0111), which are co-financed from the state budget by the Slovenian Research Agency. 


\section{Introduction}

The function of instrumental traditional music is (and was) in many cases to accompany traditional dance. It is (and was) played in the context of entertaining events, such as merriments and weddings. Traditional instruments can also be part of ritual events, but this role is less visible in instrumental traditional music research. The research of traditional music and dance in Slovenia was formalised in 1934, when the Music Society (Glasbena matica) established the Folklore Institute, today known as the Institute of Ethnomusicology at the Scientific Research Centre of the Slovenian Academy of Sciences and Arts (ZRC SAZU). ${ }^{1}$ This institute is the only institution in Slovenia that deals with systematically collecting and researching traditional music, and is in this respect comparable to similar institutions that deal with traditional music elsewhere in Europe. The Institute of Ethnomusicology also serves as the framework of this article, which aims to present past and present research of instrumental traditional music practices. The article presents a part of my ongoing research into representations of instrumental traditional music practices from the first half of the twentieth century. Although my research also refers to the work of scholars who are not part of the Institute of Ethnomusicology, I have decided for the purposes of the present article to focus specifically on the work of the Institute based on the years of fieldwork done by the Institute's associates, which has resulted in a rich audio archive that serves as the primary resource of not only my own research, but also that of others. The purpose of the article is to present the history of the research of instrumental traditional music and the foundations of research today, i.e., research done in the field of instrumental traditional music and the collected and archived material. At the same time, I would like to draw attention to some ideological orientations of researchers that have had an impact on the ways of collecting, archiving and presenting the collected material, as well as on the research that has been done in this field, or that has been omitted.

\section{Sources for the research of instrumental traditional music practices available at the Institute of Ethnomusicology}

The most reliable sources for the research of instrumental traditional music are audio and video materials obtained in the field, as well as photographic material (e.g., photographs of musicians or traditional instruments). The sound archive of the Institute of Ethnomusicology holds numerous recordings on tape and other (digital) audio carriers that have superseded tape (cassettes, DAT, hard drives), and as such is of paramount importance for the ethnomusicological

1 Hereinafter, I will refer to the Institute of Ethnomusicology at the Scientific Research Centre of the Slovenian Academy of Sciences and Arts as the Institute of Ethnomusicology. 
analyses of past and present traditional music practices.

\subsection{Tape recordings from the field}

The first field recordings of instrumental traditional music obtained for the Institute of Ethnomusicology date back to 1955, and the first tape recorder was used for recording in White Carniola (Bela krajina) between 27 and 31 January 1955. In addition to vocal music, researchers also made the first recordings of instrumental traditional music: 16 recordings of a tamburitza ensemble (tamburaški zbor), one recording of a double whistle (dvojnice) and one of a whistle (pišcal). All of the recordings feature instruments, but only as an accompaniment to singing. In December 1955, the first recording of purely instrumental music, i.e., without vocals, was made in Bogojina (Prekmurje Region), comprising ten dance tunes played on the diatonic accordion (diatonicna harmonika). In 1993, the tape recorder was replaced by more contemporary recording devices: first there was the digital audio tape or DAT, while digital recorders with internal or external discs were introduced in 2007. However, the tape recordings are the key audio documents for my research; I found that 400 of these recordings include instrumental music, revealing the soundscape of traditional music practices from the first half of the twentieth century. ${ }^{2}$

\subsection{8 rpm gramophone records}

It is only in the last decade that $78 \mathrm{rpm}$ gramophone records have been considered as a source of research in ethnomusicology. The records were made before the First World War and in the interwar period, and are considered to be the oldest audio documents of instrumental traditional music practices. These gramophone records also include arrangements of traditional music, but as they were made for commercial purposes, they have only recently been recognised as a relevant audio resource for the research of traditional music. A project called Sound Material from Gramophone Records as a Source of Ethnomusicology and Folklore Research (No. L6-2113) resulted in a vast fund of recordings of Slovenian music obtained by the Institute of Ethnomusicology. These recordings, including approximately 600 recordings of instrumental music, constitute the Digital Collection of Gramophone Records at the Institute. The collection has been the key source of several research projects, the results of which are collected mainly in a thematic edition of Traditiones 43, no. 2 (2014), and in the monograph Glasba z obeh strani (Music from Both Sides) by Rebeka and Drago Kunej, which focuses on the case of the Hoyer Trio, a

2 For more about tape recordings of instrumental music, see Teja Turk, "Odsevi etnomuzikoloških usmeritev v posnetkih inštrumentalne glasbe na magnetofonskih trakovih," Glasnik Slovenskega etnološkega društva 60, no. 2 (2020): 58-69. 
harbinger of polka music in America.

\section{Research directions and the beginnings of instrumental traditional music research}

No significant research was done on instrumental traditional music prior to the founding of the Institute of Ethnomusicology, although Zmaga Kumer does mention research on the "harmonica made of reed" (orglice iz trstike) by Davorin Beranič, which remained unfinished after Beraničs death in 1923 and is now presumably lost. ${ }^{3}$

The founder and the first director of the Institute, France Marolt, defined a programme plan that involved "the creation of a collection of Slovenian music folklore that is as comprehensive as possible, which means collecting all of the available records of traditional songs ${ }^{4}[\ldots]$ and making sure that they are updated", "organising and cataloguing the collected material [...] carrying out musicological research and making a critical book edition" and "collecting scientific publications that refer to Slovenian musical folklore". ${ }^{5}$ This was the guide for further research, which resulted in a still growing collection of recordings of and data about traditional music and dance, published research, and an established typology of traditional music and dance.

France Marolt's most important contribution to the research of traditional music was the founding and management of the Folklore Institute, which represents the (formal) foundation of Slovenian musical folkloristics. ${ }^{6}$ His notes, which were published posthumously by the Institute of Ethnomusicology as Slovenske narodoslovne študije (Slovenian Ethnography Studies), include notes on instrumental traditional music. The latter were published in 1954 in the third notebook (Gibno-zvocni obraz Slovencev/The Movement-Sound Expression of Slovenians) and the fourth notebook (Slovenski glasbeni folklore/Slovenian Musical Folklore). Marolt saw different values in "music (muska) that was produced by traditional musicians and 'music for fun' (muska za spas), which can be made by anyone". ${ }^{7} \mathrm{He}$ also differentiated between "primitive instruments" - i.e., "all sound-making objects, either homemade or handicraft objects that

3 Zmaga Kumer, Ljudska glasbila in godci na Slovenskem (Ljubljana: Slovenska matica, 1983), 11.

4 Such diction in the programme can be understood as an indicator of the selective view of musical folklore, and may have influenced the fact that less attention was devoted to instrumental music by scholars.

5 An excerpt from the Folklore Institute charter as quoted in Zmaga Kumer's "France Marolt (1891-1951): Ob stoletnici rojstva slovenskega etnomuzikologa," Traditiones 20 (1991): 14, http://www.dlib.si/?URN=URN:NBN:SI:DOC-BDE0OZFP.

6 Marolt's importance went beyond the research of music and dance traditions: he more or less defined the image of what we call Slovenian music and dance traditions by organising folklore events, as well as serving as an editor at Radio Ljubljana.

7 France Marolt, Slovenske narodoslovne študije, notebook 3: Gibno-zvočni obraz Slovencev (Ljubljana: Glasbenonarodopisni inštitut, 1954), 17. 
our people need during their work and relaxation, for their everyday tasks and celebrations mostly for their aural enjoyment, but they are not used to make music" - and "classical instruments" - i.e., instruments that are played by traditional musicians. ${ }^{8}$

Marolt did not live to see the advent of field recording undertaken by the Institute's associates (the Institute procured its first tape recorder in 1954, three years after Marolt's death). He did, however, define several guidelines that researchers should follow when working in the field. In the fourth book of Slovenske narodoslovne študije he wrote:

In the area of instruments, researchers should be mainly interested in the following items:

1. our primitive sound-making objects, their making and usage;

2. classical instruments in our musical folklore, their provenance and usage;

3. the farmer as traditional musician, his performances and repertoire;

4. style and form of Slovenian instrumental folklore;

5. Slovenian rural dances. ${ }^{9}$

Despite Zmaga Kumer's statement that ever since its establishment, the Institute of Ethnomusicology "has been constantly interested in instruments and musicians throughout the entire field research", ${ }^{10}$ considering the amount of audio material and past research, instrumental traditional music cannot be compared to traditional vocal music and to the amount of research and documentation associated with it. The first large project collecting song traditions, The Folk Song in Austria (Das Volkslied in Österreich), took place during the years between 1906 and 1913 and also comprised music collected in some of today's Slovenian provinces. The collected music was exclusively vocal, as music with text was considered a "representative form of a nation's music."11

Later, as well, ethnomusicologists preferred to focus on vocal music rather than instrumental traditional music due to their (personal and professional) interests. ${ }^{12}$ The aim of the collection and archiving of national traditional music was to "collect as many examples of antique, mostly rural vocal music,

8 Ibid.

9 France Marolt, Slovenske narodoslovne študije, notebook 4: Slovenski glasbeni folklor (Ljubljana: Glasbenonarodopisni inštitut, 1954), 16.

10 Kumer, Ljudska glasbila in godci na Slovenskem, 11.

11 Lorenc Antoni, "Mbi disa dukuri dhe mënyra të kënduarit të këngëve popullore të përfshira në blejt I-VI të 'Folklorit muzikor shqiptar'," Gjurmime albanolog jike 5 (1975): 119143, quoted in Alma Bejtullahu, "Glasba in ples narodnih manjšin v Sloveniji: Nacionalna identiteta, eksotika, past stroke," Traditiones 45, no. 2 (2016): 168, http://www.dlib. si/?URN=URN:NBN:SI:DOC-1Z29DFP0.

12 In-depth research on instrumental traditional music requires appropriate education and skills for melodic transcription, which could be one of the reasons for the smaller quantity of research. However, the number of researchers personally interested in instrumental traditional music has always been less than those interested in vocal traditional music. 
most often found within the researcher's own national or ethnic territory so as to be able to define one or more national styles." ${ }^{13}$ Due to these research orientations ${ }^{14}$ instrumental traditional music has remained "the least researched chapter in Slovenian folkloristics [...] that even our own researchers of Slovenian traditional culture have failed to take fully into account", ${ }^{15}$ as Zmaga Kumer noted in $1957 .{ }^{16}$

The associates of the Institute of Ethnomusicology therefore decided to compensate for the insufficient knowledge of instrumental traditional music practices, and in 1958 published two questionnaires in Glasnik Slovenskega etnološkega drustva (Bulletin of the Slovenian Ethnological Society) on instruments and traditional music making. The feedback to the first questionnaire on simple and childhood instruments was good, while the questionnaire on traditional music and musicians received fewer responses. Nevertheless, the answers received were a great help in the search for traditional musicians, whom researchers later visited and recorded based on the information from the questionnaires. ${ }^{17}$

\section{Instrumental music in the research of the associates of the Institute of Ethnomusicology}

As in the case of the research of traditional vocal music and dance, the research done so far on instrumental traditional music practices has been mostly limited to the Slovenian space, i.e., to the territory of the modern-day Republic of Slovenia, along with the regions in neighbouring countries inhabited by a Slovenian minority, which researchers have considered as relevant areas for the research of Slovenian folk creativity. Due to the tendency to research Slovenian music, other ethnic minorities in Slovenia were not (or were rarely) recorded or included in the past research done by the Institute's associates. Zmaga Kumer, Julijan Strajnar, Igor Cvetko, Maša Komavec, Drago Kunej, Mojca Kovačič and myself are among the researchers of the Institute of Ethnomusicology who have dealt with instrumental traditional music practices from different standpoints. I would first like to highlight the work of $Z$ maga Kumer and Igor Cvetko, who were the first to research this specific area of traditional music

13 Svanibor Pettan, “K drugi godbi Roberta Leydija," foreword to Druga godba: Etnomuzikologija, by Roberto Leydi (Ljubljana: ŠKUC in Filozofska fakulteta, 1995), 315.

14 The research orientations mentioned were established in the first half of twentieth century, but influenced the research in the second half of twentieth century, as well.

15 Zmaga Kumer, "Paberki o slovenskih ljudskih glasbilih," Glasnik Slovenskega etnološkega društva 1, no. 4 (1957): 24.

16 This claim is inconsistent with a later statement by Zmaga Kumer in 1983 (mentioned above), in which she stated that the Institute's associates had been constantly interested in instrumental music since its establishment (Kumer, Ljudska glasbila in godci na Slovenskem,11).

17 For further information on research orientations, see also Turk, "Odsevi etnomuzikoloških usmeritev". 
practices as a whole.

Zmaga Kumer dedicated the majority of her research opus to traditional song. As mentioned above, she was nonetheless aware of the gaping hole in the research of instrumental music, and she tackled this area as well, starting with the articles "Godčevski in plesni motivi na panjskih končnicah"18 ("Traditional Instrumental Music and Dance Motives on Beehive Panels") and "Primitivna instrumentalna glasba in ples v slovenski narodni pesmi"19 ("Primitive Instrumental Music and Dance in Slovenian Traditional Song”). In both cases, she focused on two (indirect) sources - images from beehive panels and traditional music - that originate in the time when there were no audio recordings. ${ }^{20}$ The lack of audio material meant that the only available source for the research of instruments was fine art presentations and people's testimonies, despite being the result of unverified personal interpretations. The work by Zmaga Kumer that contributed most to the research of instrumental traditional music is the monograph Ljudska glasbila in godci na Slovenskem (Traditional Music Instruments and Traditional Musicians in Slovenia). ${ }^{21}$ The monograph is still considered to be the only fundamental, comprehensive and encyclopaedic work on traditional instruments in Slovenia as understood by researchers of that time. Zmaga Kumer was very consistent in the use of the word glasbilo (a Slovenian synonym for musical instrument) instead of inštrument (instrument), which according to her has a rather broader meaning, not necessarily connected to music. ${ }^{22}$ Moreover, she does not hierarchically differentiate musical instruments as did France Marolt, who classified them into primitive and traditional groups. Kumer accepts any instrument as a traditional instrument, i.e., any object that can be purposefully used to create sounds that are considered music, and that "traditional musicians use to play tunes from folk traditions on such occasions that fit into their framework, and objects that traditional usage values as musical instruments". ${ }^{23}$ The monograph systematically classifies instruments according to the Hornbostel-Sachs classification system: it includes data on sources and the extent of usage in space (Slovenia and Europe) and time, as well as noting the dialectal names of instruments, their structure and

Zmaga Kumer, “Godčevski in plesni motivi na panjskih končnicah,” Slovenski etnograf 10 (1957): 157-166, http://www.dlib.si/?URN=URN:NBN:SI:DOC-YOBXHMQQ.

19 Zmaga Kumer, "Primitivna instrumentalna glasba in ples v slovenski narodni pesmi," in Rad kongresa folklorista Jugoslavije, eds. Vinko Žganec, Zoran Palčok and Cvjetko Rihtman (Zagreb: Savez Udruženja Folklorista Jugoslavije, 1958), 79-90.

20 The recordings on the $78 \mathrm{rpm}$ gramophone records, which are considered the oldest audio documents of instrumental traditional music, were neither available nor known to the researchers in the post-war period.

21 It was first published in 1972 as Slovenska ljudska glasbila in godci, while an updated edition entitled Ljudska glasbila in godci na Slovenskem was issued in 1983.

22 Kumer, Ljudska glasbila in godci na Slovenskem, 8.

23 Ibid. 
their way of playing.

Igor Cvetko's research largely focused on children's sound toys and simple musical instruments. Prior to his work, this field of research had been treated in the same way as the instrumental traditional music practices of adults, disregarding the differing laws of the child's world, which Cvetko takes into account in his work. He uses two expressions to denote instruments, the traditional glasbilo (in the sense of a traditional musical instrument) and zvocilo (a sound-making object), giving the latter a broader meaning that includes sound toys, a whip, bells, etc. According to Cvetko's definition, the category of children's musical instruments includes objects found in nature (e.g., a stone, a leaf), instruments made by children or by adults for children, and industrially made instruments, e.g., the mouth organ (ustna harmonika). He highlights children's play as the most natural childhood activity, which is the key framework for the usage of children's instruments and sound toys. ${ }^{24}$ According to the archaeological findings and their comparison with modern-day children's musical instruments "children's experience and expressive worlds have not changed since prehistoric times", ${ }^{25}$ so musical instruments for children and sound toys have also changed little in their form and type (e.g., rattle, whistles, percussion), although noticeable changes can be found in the materials. Cvetko classified musical instruments for children and sound toys found in Slovenia according to their origin and applied the Hornbostel-Sachs classification system.

In addition to researching children's musical instruments, Igor Cvetko also undertook in-depth research on the case of wooden horns in Slovenia from historical and modern day perspectives. ${ }^{26}$ In 2007, he mounted an exhibition called Zvoki Slovenije (Sounds of Slovenia) at the Slovene Ethnographic Museum, ${ }^{27}$ which presented the timeline of instrumental music in Slovenia from prehistoric findings to the revival of traditional music, and also included the connections that traditional music has developed with the mass media and popular culture, thus opening up an important field of questioning the boundaries between traditional and popular music.

While these two studies provide an overview of the field as a whole, the article continues with a look at case studies of individual musical instruments: the violin played in the Resia Valley (citira), panpipes (trstenke) and the diatonic

24 Igor Cvetko, "Otroška glasbila in zvočne igrače kot del glasbene (zvočne) tradicije otrok na Slovenskem," in Med godci in glasbili: Razgledi, ed. Igor Cvetko (Ljubljana: Slovenski etnografski muzej: ZRC SAZU, ISN, Sekcija za glasbeno narodopisje, 1991), 54.

25 Cvetko, "Otroška glasbila in zvočne igrače," 64.

26 Igor Cvetko, “O lesenih rogovih in rogistih na Slovenskem," Etnolog 12, no. 1 (2001): 285-300, http://www.dlib.si/?URN=URN:NBN:SI:DOC-8N95Y98W.

27 Igor Cvetko, Zvoki Slovenije: Od ljudskih godcev do avsenikov; exhibition (Ljubljana: Slovenski etnografski muzej, 2007). 
accordion.

The research of the citira ${ }^{28}$ is based on findings obtained in the field in the Resia Valley in Italy. ${ }^{29}$ Its author, Julijan Strajnar, is an ethnomusicologist and an academically trained violinist. It was his interest in the violin that spurred him to research instrumental music, while his expertise and knowledge of the violin allowed him to analyse the citira in detail. The expressions he uses for instruments in the sphere of traditional music are glasbilo, glasbilo-instrument, ljudsko glasbilo, ljudski inštrument ${ }^{30}$ or godčerski sestav (group of traditional musicians) for a music group. He defined several methodological guidelines that ethnomusicologists should follow in their research: besides looking at melody and rhythm, "they should also be interested in, for example, embouchure, fingers position, bowing technique, the use of vibrato, etc. [...] These details help us observe and better understand the style of a specific traditional musician, the style of a place or a region, the development of a melody, etc." ${ }^{11}$ Strajnar applied this methodology thoroughly in his research of the citira: he studied its acoustic characteristics, compared parts of the instrument with parts of the concert violin, paid special attention to the technique and the style of playing, and included all of the details in his music transcriptions. He analysed Resian melodies from different perspectives: tempo, melody, harmony and metre. By analysing not only the instrument and its use but also the repertoire and connections to Resian dance, Strajnar carried out some of the most comprehensive research of a specific area and produced one of the few studies that include all of the elements that we have mentioned and that are closely connected in practice.

The associates of the Institute of Ethnomusicology first became interested in panpipes ${ }^{32}$ when they received answers to the questionnaire on traditional musical instruments published in the Bulletin of Slovenian Ethnological

28 Citira is a Resian colloquial expression for the fiddle. Although their instruments are made in factories or by craftsmen, Resians always modify them: they lower the bridge, move the sound post and tune the instrument to at least minor third higher than the usual violin tuning. See Julijan Strajnar, Citira: La musica strumentale in Val di Resia/Citira: Inštrumentalna glasba v Reziji (Udine/ Videm: Edizioni Pizzicato; Trieste/Trst: Založništvo tržaškega tiska, 1988), 21-24.

29 Resia is a border area in Italy, which is considered to be a Slovenian ethnic area, as Resians speak (or spoke) an old Slovenian dialect.

30 Both expressions, ljudsko glasbilo and ljudski instrument, have the same meaning: a traditional instrument.

31 Julijan Strajnar, "Raziskovanje glasbil in instrumentalne glasbe: Principi in metode dela," in Zbornik radova in čast akademika Crujetka Ribtmana, ed. Borivoj Čović (Sarajevo: Akademija nauka i umjetnosti Bosne i Hercegovine, 1986), 141.

32 The panpipes known in the Slovenian space are symmetrical in shape with the longest tube in the middle. The number of tubes can vary, but must always be an odd number due to the symmetry of their layout. Before the twentieth century, panpipes were quite widespread in the Slovenian space. They were preserved for the longest time in central Styria, where they retained their regional recognition. 
Society in 1958, which included information on this instrument from the Styria and Carinthia regions. Drago Kunej, whose knowledge of panpipes stems from both ethnomusicological research and his own practice, researched the story of Franc Laporšek, possibly the last traditional musician who played panpipes and who also had an important role in the revival of this instrument. Franc Laporšek's performance on panpipes was first recorded by the Institute's associates in 1969 . He was subsequently invited to numerous folkloristic events $^{33}$ and interest in the instrument began to grow, ${ }^{34}$ which encouraged him to take the making of panpipes more seriously. As "the last folk musician to play panpipes", ${ }^{35}$ Laporšek appeared at numerous concerts as well as on radio and television. In addition, ethnomusicologists and performers alike became interested in making the instruments. Among them, particular mention should be made of Mira Omerzel, Matija Terlep, the Kurja Koža Trio (their repertoire was based on panpipes that they had learned to play with Laporšek) and Tomaž Rauch. In this way, the music practice of playing on panpipes has been preserved, although, as Kunej points out, their function has shifted from a traditional musical instrument to "a presentation of past tradition on stage and in the education process". ${ }^{36}$

At the beginning of the twentieth century, the diatonic accordion rapidly gained popularity and became a ubiquitous instrument in the area of traditional music, as well. It was used by traditional musicians as well as by performers of popular music genres similar to traditional music, such as pop-folk music (narodnozabavna glasba) and polka music (in America). Accordion players were also popular radio guests in the 1930s, the early years of radio broadcasting. The field recordings of the Institute of Ethnomusicology reveal that the accordion is present in most traditional instrumental groups, and by 1990 it had appeared as a solo instrument on approximately $200^{37}$ recording tapes, which demonstrates how popular it was among traditional musicians.

Among the research on the accordion done by the Institute's associates, the work of Maša Komavec and Mojca Kovačič deserves particular mention. The new generation of ethnomusicologists, including Komavec and Kovačič, approach the research of musical instruments differently than the post-war generation. As well as viewing traditional music from the folkloristic perspective, they also look at it from the anthropological and sociological standpoints, among others. Instead of analysing the musical instrument itself (which has

33 Drago Kunej, “'Jaz nisem muzikant, jaz sem ljudski godec': Vloga Franca Laporška pri revitalizaciji trstenk," Traditiones 45, no. 2 (2016): 89-90, https://doi.org/10.3986/Traditio2016450206.

34 Ibid., 91.

35 Ibid., 89.

36 Ibid., 97.

37 This corresponds to approximately half of all of the tapes that document instrumental music. I gather that the total number of accordion recordings is around 2,000. 
already been done, for example, by Zmaga Kumer ${ }^{38}$ both researchers focus on the role of the accordion in society. Maša Komavec's research was among the first to include the influence of pop-folk music on the popularisation of the accordion. It led to changes in the repertoire, the structure of music groups and the attitude towards the instrument itself. The accordion has thus become the instrument with which people most often identify, although its aesthetic value is often a source of disagreement.

The functional role and repertoire of accordion music has become strongly linked to popular music (mainly the pop-folk genre), resulting in it becoming less valued artistically and aesthetically in intellectual circles as well as by scholars. ${ }^{39}$ Still, it cannot be denied that the accordion plays an important role in the national identification process, and pop-folk music events are still very well attended today: the audience likes this genre a great deal and identifies with it. ${ }^{40}$

Mojca Kovačič deals with this topic in her article " $V$ deželi harmonike nacionalizacija harmonike v slovenskem kontekstu" ${ }^{41}$ ("In the Land of the Accordion - The Nationalisation of the Accordion in the Slovenian Context"), highlighting the phenomenon of the nationalisation ${ }^{42}$ of the accordion in the context of pop-folk, polka and other popular music genres. Folklorists and ethnomusicologists used to view the latter as a digression from traditional music with regard to its value and aesthetics, so these genres were of little interest to them. The two researchers have broadened the scope of popular music genres; furthermore, a substantial shift has occurred in the understanding of traditional music practice, which "at this point does not only refer to the institutional understanding of the traditional based on music traditions, but also to music practices that are a part of the life of the wider population." ${ }^{43}$

Relevant research has also been done by researchers of traditional music practices outside the Institute's framework. Particular mention should be made of Radoslav Hrovatin (drone zither (bordunske citre), jew's harp (drumlica), a children's sound toy made of reed called nunalca), Milan Trampuš,

Kumer, Ljudska glasbila in godci na Slovenskem, 89-94.

39 The use of other types of accordion (e.g., the piano accordion and the chromatic button accordion, the bandoneon) in some genres that have spread across Slovenia in the last few years (e.g., the tango, the concert accordion in classical music) is aesthetically more acceptable and more valued artistically in intellectual circles, while the diatonic accordion is linked to pop-folk music, which is not highly valued among intellectuals and musicologists.

40 See Mojca Kovačič, "V deželi harmonike - nacionalizacija harmonike v slovenskem kontekstu," in Venček domačih: Predmeti, Slovencem sveti, ed. Jernej Mlekuž (Ljubljana: ZRC SAZU, 2015).

41 Ibid.

42 Kovačič also researched bell chiming (pritrkavanje) in the context of nationalising this instrumental practice, which is connected not to dance music, but to ritual music practice. See Mojca Kovačič, Pa se sliš ... Pritrkavanje v slovenskem in evropskem prostoru (Ljubljana: Založba ZRC SAZU, 2012).

43 Kovačič, "V deželi harmonike," 87. 
Mira Omerzel (zither (citre), diatonic dulcimer (diatonični oprekelj) and cymbal (cimbale)), Dario Marušić (instruments from Istria), Nina Volk (diatonic accordion, diatonic dulcimer), Romeo Volk (diatonic dulcimer, traditional instrumental music groups in the Ilirska Bistrica area), Drago Hasl (a type of whistle called žvegla), Emil Zonta (triestina accordion), Tomaž Rauch (panpipes, clay bass (lonceni bas), mouth organ), and Bruno Ravnikar (music acoustics and analysis of musical instruments). Most of these researchers have not only researched the instruments, but are (or were) also active performers of traditional music. Their extensive research contributes significantly to the study of traditional music practices. The studies of musical instruments are detailed and as such represent a good foundation for further research in the area of instrumental music.

The research I am currently conducting is based on the connections between instrumental traditional music and cultural identities of Slovenians from the first half of the twentieth century. It will contribute significantly to the research of instrumental traditional music done so far, i.e., the research done from ethnographic and anthropological standpoints. My work focuses on musical instruments and instrumental music groups that are recognised by musicians, researchers or the mass media as local, regional or of national importance (e.g., tamburitza ensemble, wind bands, diatonic accordion, panpipes). One of the aims of the research is to learn how specific instruments or instrumental music groups are connected to the cultural identities of Slovenians. We can assume that various factors have affected geographically recognisable musical instruments. One of them is the music repertoire that has been audio documented mostly by the Institute of Ethnomusicology and has been consequently included in the concert repertoire of musicians today.

In addition, an analysis will be carried out of the changes in instrumental traditional music brought about by the development of mass media and popfolk music. The first half of the twentieth century gave rise to new technologies and mass media - the research highlights gramophone records and the radio - while new genres of popular music developed on the foundation of traditional music, e.g., polka and pop-folk music. These genres were widely popular among the people and as such had a considerable impact on the public image of traditional music; with their editorial policies, the media were able to stimulate the growth of certain music genres or music groups, while performers contributed to the repertoire of instrumental music with their own choices, whether they performed on stage or on the radio, or were recorded either by field researchers or for publishing on $78 \mathrm{rpm}$ gramophone records. A survey of the tape recordings from the audio archives of the Institute of Ethnomusicology and of the $78 \mathrm{rpm}$ gramophone records from the Digital Collection of Gramophone Records has shown that certain instruments and instrumental music groups stand out. The (diatonic) accordion is distinctly prevalent among 
the musical instruments that were recorded on gramophone records in America; the instrument had a symbolic value for Slovenian immigrants, who were connected to their homeland. The accordion is also prevalent, although to a lesser extent, on field recordings of the Institute of Ethnomusicology's sound archive. These recordings also show that apart from the apparently numerous recordings of the accordion, recordings of some instrumental music groups are tied to specific places or regions (for example the tamburitza ensemble in White Carniola, the Prekmurje band in the Prekmurje region, the violin (citira) and three-stringed bass or violoncello (bunkula) in the Resia Valley).

\section{Conclusion}

The research of instrumental traditional music carried out by the Institute of Ethnomusicology is not abundant in terms of the number of studies, as researchers used to focus mostly on the research of vocal traditional music due to the recognisability of language as an identifier of nationality. Nevertheless, the foundations for further research of instrumental traditional music and its social role were laid, especially with the detailed overview of the existing musical instruments in traditional usage in Slovenia in Zmaga Kumer's anthology. ${ }^{44}$ Early (i.e., post-war) research concentrated mainly on an overview of past and existing traditions in order to preserve our knowledge of instrumental traditional music practices. The research of musical instruments at the time favoured the analysis of an instrument, its mechanical functioning and structure, dialectal names and the circumstances in which an instrument was (or instruments were) played. The musicians' repertoire was less of interest; it was often tied to dance and so was mostly in the domain of ethnochoreological research. ${ }^{45}$

Later ethnomusicological research has been more broadly based and more interdisciplinary. Its purpose is to show the role of a musical instrument and instrumental traditional music in society and to observe changes as they occur through time as the result of social changes. Instrumental traditional music is seen as a living process. It is not a static, socially isolated phenomenon; on the contrary, it is a constituent part of society. ${ }^{46} \mathrm{In}$ the past, researchers used to have a rather negative attitude towards the mass media and pop-folk music genres, believing that these not only change but also devalue folk traditions. Therefore, mass media and pop-folk music were understood as a deviation from traditional music and the traditional music field of research. Today, research has changed its outlook: mass media and pop-folk music genres are seen as factors that have an

5 Research of traditional instrumental music and dance was rarely intertwined. Studies that connect both are, e.g., Strajnar, Citira and Marjeta Tekavec, Vplivi godčevstva na oblikovanje slovenskega plesnega izrocila (Ljubljana: University of Ljubljana, 1999).

46 This is also true of contemporary research of traditional vocal music and dance. 
important connection with traditional music and the influence on performative practices goes both ways. At the same time, the understanding of the traditional has expanded beyond the past frameworks. Researchers take into account contemporary music practices as well as urban music practices and sound studies ${ }^{47}$ (in the past, the emphasis was on the rural environment) and groups of people who are considered marginal and have so far been neglected (e.g., immigrants, refugees, ethnic minorities). ${ }^{48}$ Including these aspects into research creates a comprehensive soundscape of time or space and reveals individual practices from the past that used to be omitted due to the selection of music materials.

\section{Bibliography}

Antoni, Lorenc."Mbi disa dukuri dhe mënyra të kënduarit të këngëve popullore të përfshira në blejt I-VI të 'Folklorit muzikor shqiptar'." Gjurmime albanolog jike 5 (1975): 119-143. Quoted in Bejtullahu, Alma. "Glasba in ples narodnih manjšin v Sloveniji: nacionalna identiteta, eksotika, past stroke." Traditiones 45, no. 2 (2016):159-176. https:// doi.org/10.3986/Traditio2016450210.

Cvetko, Igor. "Otroška glasbila in zvočne igrače kot del glasbene (zvočne) tradicije otrok na Slovenskem." In Med godci in glasbili: Razgledi, edited by Igor Cvetko. Ljubljana: Slovenski etnografski muzej: ZRC SAZU, ISN, Sekcija za glasbeno narodopisje, 1991.

Cvetko, Igor, ed. Med godci in glasbili: Razgledi. Ljubljana: Slovenski etnografski muzej: ZRC SAZU, ISN, Sekcija za glasbeno narodopisje, 1991.

Cvetko, Igor. "Kako sploh arhivirati instrumentalno glasbo na Slovenskem?" Traditiones 21 (1992): 241-244. http://www.dlib.si/?URN=URN:NBN:SI:DOC-GDVFHFYW.

Cvetko, Igor. "O lesenih rogovih in rogistih na Slovenskem." Etnolog 12, no. 1 (2001): 285300. http://www.dlib.si/?URN=URN:NBN:SI:DOC-8N95Y98W.

Cvetko, Igor. Zvoki Slovenije: Od ljudskih godcev do avsenikov. Exbibition, 22. november 2007-september 2008. Ljubljana: Slovenski etnografski muzej, 2007.

Komavec, Maša. “Ti igraš za lepoto glasbe, ti ne igraš zati, ki igraš, ti moraš nardit lepe zvoke: O harmoniki v severni Istri'." In Istarski muzikološki susreti/Istrska etnomuzikološka srečanja/Incontri etnomusicologici istriani 2000-2001, edited by Naila Ceribašić and Ines Greblo, 17-20. Roč: KUD “Istarski željezničar”, 2002.

Kovačič, Mojca. "Kako naj zveni mesto: Religijski in ulični zvoki Ljubljane med izkustvom in zakonodajo." Etnolog 28 (2018): 123-140. http://www.dlib. si/?URN=URN:NBN:SI:DOC-EMA8SA3N.

Kovačič, Mojca. Pa se sliš ... Pritrkavanje v slovenskem in evropskem prostoru. Ljubljana: Založba ZRC, ZRC SAZU, 2012.

Kovačič, Mojca. "Kje so ljudski godci?': Refleksija preteklih konceptov in možnosti novih opredelitev ljudskega godčevstva." Glasnik Slovenskega etnološkega društva 54, no. 3 (2014): 12-20. http://www.dlib.si/?URN=URN:NBN:SI:DOC-ZA6DCC0G.

Kovačič, Mojca. "V deželi harmonike - nacionalizacija harmonike v slovenskem kontekstu." In Vencék domačib: Predmeti, Slovencem sveti, edited by Jernej Mlekuž, 87-116. Ljubljana: ZRC SAZU, 2015.

47 See, e.g., Mojca Kovačič, "Kako naj zveni mesto: Religijski in ulični zvoki Ljubljane med izkustvom in zakonodajo," Etnolog 28 (2018): 123-140, http://www.dlib.si/?URN=URN:NBN:SI: DOC-EMA8SA3N.

48 See Muzikološki zbornik 55, no. 2 (2019). 
Kumer, Zmaga. "Paberki o slovenskih ljudskih glasbilih." Glasnik Slovenskega etnološkega društva 1, no. 4 (1957): 24.

Kumer, Zmaga. "Godčevski in plesni motivi na panjskih končnicah.” Slovenski etnograf 10 (1957): 157-166. http://www.dlib.si/?URN=URN:NBN:SI:DOC-YOBXHMQQ.

Kumer, Zmaga. "Primitivna instrumentalna glasba in ples v slovenski narodni pesmi." In Rad kongresa folklorista Jugoslavije, edited by Vinko Žganec, Zoran Palčok and Cvjetko Rihtman, 79-90. Zagreb: Savez Udruženja Folklorista Jugoslavije, 1958.

Kumer, Zmaga. Slovenska ljudska glasbila in godci na Slovenskem. Ljubljana: Slovenska matica, 1983.

Kumer, Zmaga. "France Marolt (1891-1951): Ob stoletnici rojstva slovenskega etnomuzikologa." Traditiones 20 (1991): 9-28. http://www.dlib.si/?URN=URN:NBN:SI: DOC-BDE0OZFP.

Kunej, Drago. "Prva magnetofonska snemanja za zvočni arhiv Glasbenonarodopisnega inštituta.” Traditiones 28, no. 2 (1999): 217-232. http://www.dlib. si/?URN=URN:NBN:SI:DOC-ZMTVIEZV.

Kunej, Drago: “Slovenski posnetki na gramofonskih ploščah z 78 o/min.” Traditiones 43, no. 2 (2014): 11-29. https://doi.org/10.3986/Traditio2014430201.

Kunej, Drago. "Leto 1908 - začetek diskografije slovenske glasbe.” Traditiones 43, no. 2 (2014): 51-73. https://doi.org/10.3986/Traditio2014430203.

Kunej, Drago. “Jaz nisem muzikant, jaz sem ljudski godec': Vloga Franca Laporška pri revitalizaciji trstenk." Traditiones 45, no. 2 (2016): 83-101. https://doi.org/10.3986/ Traditio2016450206.

Kunej, Drago. Fonografje dospel. Prvi zvočni zapisi slovenske ljudske glasbe. Ljubljana: Založba ZRC, ZRC SAZU, 2008.

Kunej, Drago, and Rebeka Kunej. Glasba z obeb strani: Gramofonske plošče Matije Arka in Hoyer tria. Ljubljana: ZRC SAZU, 2016.

Marolt, France. Slovenske narodoslovne študije, 3. zvezek: Gibno-zvočni obraz Slovencev. Ljubljana: Glasbenonarodopisni inštitut, 1954.

Marolt, France. Slovenske narodoslovne študije, 4. zvezek: Slovenski glasbeni folklor. Ljubljana: Glasbenonarodopisni inštitut, 1954.

Pettan, Svanibor. “K drugi godbi Roberta Leydija.” Foreword to Druga godba: Etnomuzikologija, by Roberto Leydi, 312-320. Ljubljana: ŠKUC in Filozofska fakulteta, 1995.

Strajnar, Julijan. "Nekaj o harmoniki in godcih." Folklorist 7, no. 2 (1984): 22-23.

Strajnar, Julijan. "Ljudska glasba na slovenskem.” Folklorist 8, nos. 1-2 (1985): 26-38.

Strajnar, Julijan. "Godci in godčevstvo na slovenskem." Folklorist 9, nos. 1-2 (1986): 4-10.

Strajnar, Julijan. "Godčevske viže.” Folklorist 9, no. 1-2 (1986): 11-13.

Strajnar, Julijan. "Raziskovanje glasbil in instrumentalne glasbe: Principi in metode dela." In Zbornik radova in čast akademika Cvjetka Ribtmana, edited by Borivoj Čović, 139-142. Sarajevo: Akademija nauka i umjetnosti Bosne i Hercegovine, 1986.

Strajnar, Julijan. Citira: La musica strumentale in Val di Resia/Citira: Inštrumentalna glasba v Reziji. Udine/Videm: Edizioni Pizzicato; Trieste/Trst: Založništvo tržaškega tiska, 1988.

Tekavec, Marjeta. Vplivi godčerstrva na oblikovanje slovenskega plesnega izročila. Ljubljana: University of Ljubljana, 1999.

Turk, Teja. “Odsevi etnomuzikoloških usmeritev v posnetkih inštrumentalne glasbe na magnetofonskih trakovih.” Glasnik Slovenskega etnološkega društva 60, no. 2 (2020): 58-69. 


\section{POVZETEK}

\section{Dinamika raziskav inštrumentalnih ljudskoglasbenih praks v okviru Glasbenonarodopisnega inštituta ZRC SAZU}

V prispevku je predstavljena zgodovina raziskovanja inštrumentalne ljudske glasbe in temelji, ki so bili postavljeni za raziskovanje te tematike v današnjem času; v to so vključene tako opravljene raziskave na področju inštrumentalne ljudske glasbe kot tudi zbrano in arhivirano gradivo. Raziskave ljudske glasbene in plesne tradicije na Slovenskem so dobile institucionalne temelje z letom 1934, ko je Glasbena matica ustanovila Folklorni inštitut - današnji Glasbenonarodopisni inštitut ZRC SAZU. Ta predstavlja tudi okvir pričujočega prispevka, saj so sodelavci omenjenega inštituta $\mathrm{z}$ zbiranjem in snemanjem gradiva na terenu poskrbeli za nastanek bogatega zvočnega arhiva. Zvočni arhiv je najpomembnejša zbirka zvočnih dokumentov tudi za današnje raziskave. Za mojo raziskavo so relevantni predvsem terenski posnetki na magnetofonskih trakovih in gramofonske plošče z $78 \mathrm{o} / \mathrm{min}$, na katerih se med drugimi zvrstmi nahajajo tudi priredbe ljudske glasbe. Prvi terenski posnetki inštrumentalnih ljudskoglasbenih praks so nastali leta 1955 , omenjene gramofonske plošče pa so nastale $v$ času pred prvo svetovno vojno in med obema vojnama. Iz tega časa drugih zvočnih virov nimamo, zato te plošče lahko štejemo za najstarejše zvočne zapise inštrumentalnih ljudskoglasbenih praks. Namen prispevka je obenem opozoriti na nekatere idejne usmeritve raziskovalcev, ki so pomembno vplivale na zbiranje, arhiviranje in javno predstavljanje zbranega gradiva in raziskav, ki so bile oziroma niso bile na tem področju opravljene. Opazna je razlika tako med številom raziskav kot terenskimi posnetki inštrumentalne in vokalne ljudske glasbe; slednjih je bistveno več. Med širše zastavljenimi raziskavami izpostavljam raziskavo ljudskih glasbil Zmage Kumer in raziskavo otroških glasbil Igorja Cvetka. Bolj specializirane raziskave posameznih glasbil so opravili Julijan Strajnar na primeru violine cítire, Drago Kunej na primeru trstenk, Maša Komavec in Mojca Kovačič na področju diatonične harmonike. Moja raziskava se osredotoča na povezave med inštrumentalnimi ljudskoglasbenimi praksami in kulturnimi identifikacijami med Slovenci v prvi polovici 20. stoletja. To je obdobje novih množičnih medijev in popularnoglasbenih žanrov, ki so bili povezani z ljudsko glasbo. Na podlagi analize doslej malo raziskanih virov želim ugotoviti, katera glasbila in inštrumentalne zasedbe so v Slovencih vzbudile kulturne identifikacije, pri čemer upošteva tako vlogo raziskovalcev in godcev kot množičnih medijev v tem procesu.

\section{ABOUT THE AUTHOR}

TEJATURK (teja.turk@zrc-sazu.si) is a university graduate musicologist and sociologist of culture. She is currently employed as a young researcher at the ZRC SAZU Institute of Ethnomusicology. The doctoral thesis she is conducting focuses on the connections between instrumental traditional music practices and cultural identities of Slovenes in the first half of the twentieth century.

\section{O AVTORICI}

TEJATURK (teja.turk@zrc-sazu.si) je univerzitetna diplomirana muzikologinja in sociologinja kulture. Trenutno je zaposlena kot mlada raziskovalka na Glasbenonarodopisnem inštitutu ZRC SAZU. Doktorska disertacija, ki jo pripravlja, se osredotoča na povezave med inštrumentalnimi ljudskoglasbenimi praksami in kulturnimi identitetami Slovencev v prvi polovici 20. stoletja. 